\title{
Office and Industrial Workers Complaint Detection and Prevention of Professional Upper Limb Overuse
}

\author{
Viive Pille ${ }^{1}$, Varje-Riin Tuulik ${ }^{2}$, Piia Tint ${ }^{1}$, Viiu Tuulik ${ }^{3}$, Aaro Hazak ${ }^{4}$, \\ ${ }^{1,3,4}$ Tallinn University of Technology, ${ }^{2}$ Tallinn University Haapsalu College
}

\begin{abstract}
Work-related musculoskeletal disorders have a high frequency of occurrence, and they often cause temporary or permanent disability of the neck, shoulders, arms and back and pain complaints with respect to other muscles. In the present study, we investigated 66 office workers, 18 industrial workers from wood and textile industries and 40 SPA service workers. The pain complaints were mapped with the 10 -point scale. The localization of the pain was assessed with the Nordic Musculoskeletal Questionnaire. 66 office workers and 18 industrial workers were investigated with the help of myometry. The latter method enables to determine the fatigue and elasticity of the muscles. The main aim was to identify the occupational risk factors - possible developers of MSDs in the early stage of disturbances, thus preventing the formation of the chronic diseases and disabilities.
\end{abstract}

Keywords - Musculoskeletal disorder, balneology, physical overload, risk assessment, upper limb, back pain.

\section{INTRODUCTION}

Musculoskeletal disorders are the most common workrelated health problem. Nearly $25 \%$ of the EU-25 workers are suffering from the back pain and $23 \%$ complain of other muscular pains. Both conditions are more prevalent in the new member states $-39 \%$ and $36 \%$ [1], [2].

Within the EU project "Fit for Work?", Europe workingage population's musculoskeletal morbidity was investigated (27 countries in Europe were involved) and the survey report was prepared for each participating country [3], [4]. The Estonian report has shown that the musculoskeletal disorders (MSDs) cut employees' ability to work at least by $50 \%$. It is stated that the rate of employees exposed to chemicals is much less than those exposed to the hazards causing MSDs [5].

Repetitive tasks with hands, back and neck cause the loss of work capacity in the long-term practice. In 2009 the work capacity of $59 \%$ of workers at the age of 15-64 was limited due to long-term problems with hands, legs, back or neck in Estonia [6]. There is a Centre of Excellence at the Health Promotion and Rehabilitation, Tallinn University Haapsalu College, whose mission is to promote research based rehabilitation methods for the working-age population. We need the tools to prevent these conditions and undertake rehabilitation measures before permanent loss of work capacity occurs.

The aim of the paper is to describe the theoretical basis regarding the development of the musculoskeletal disorders, the nature of rehabilitation methods, cost effectiveness of prevention and rehabilitation; the practical ways to test the musculoskeletal disorders at the early stage, the principles of balneology and the effectiveness of rehabilitation and recommendations to "return to prevention" idea benefits [7].

\section{THEORETICAL BASIS}

\section{A. Development of Musculoskeletal Disorders}

Work-related MSDs have accounted for a significant proportion of work injuries and workers' compensation claims in industrial countries since the late 1980s [8]. A complete understanding of this important occupational health problem requires further elucidation of pathophysiological mechanism of tissue response, particularly at the early stage of these disorders. Work-related MSDs of neck and shoulder have been associated with several kinds of occupations and types of work, from those categorized as being physically demanded, such as farm work and patient care to those that are considered to be fairly static, such as dental work, work at video display terminals, sewing machine operators and office workers, especially computer users. Whereas heavy physical work is associated with degenerative changes, static work is more often connected with tension neck syndrome (myofascial pain) or myalgia, local muscular pain, sore and movement resistance. Static work concentrates on smaller muscle groups, which may be selectively overloaded through prolonged activation of some of the fibres in those muscles. Exposure to static muscle activity is a well-established risk factor for musculoskeletal disorders, especially with regard to neck shoulder pain [9]. It is possible to measure the trapezius muscle tone using Myoton-2 myometer [10]. Both workrelated physical and psychosocial factors showed strong associations with low-back pain and upper-extremity complaints. The work-related physical factors did not influence the absence of sickness, whereas the psychosocial factors showed some associations with sickness absence [11].

In the previous study [12] of the Estonian garment workers MSDs, 230 garment workers (group A, 16 men and 214 women) were involved. The mean age of the investigated group was 36.2 years. Only 36 totally healthy persons $(16 \%$ of all examined) were identified in the sewers' group. The controlgroup (B) consisted of 33 persons ( 7 men, 26 women) of the management personnel (quality managers, sail agents, technologists, project managers, storekeepers, etc.). In the control-group (B), $72.7 \%$ of workers had no MSDs and were recognized healthy in this respect. Some employers among the management $(12 \%)$ had worked as blue-collar workers (sewers) in the past. The mean age of the control group workers was 36.8 years. 
The main complaints indentified in the study were as follows: in group A: shoulder pains (27\%), lower back pains $(46 \%)$, pain in the neck area $(21 \%)$, headache and fatigue of the head $(15 \%)$, carpal channel syndrome - moderate stadium $(18 \%)$, back pain in the pectoral region $(8 \%)$, fatigue of hands and disturbances in the sensitiveness $(16 \%)$, pain in the hip $(2 \%)$, pain in the leg muscle $(7 \%)$, knee pains $(6 \%)$, pain in thigh muscle (2\%), back pain $(8 \%)$. Group B: upper limb pains $(3 \%)$, lower limb pains (12\%), pain in the neck (3\%), headache and fatigue of the head $(3 \%)$, knee pains $(3 \%)$, no carpal channel syndrome.

\section{B. Mud and Hot Treatment as Rehabilitation Means}

Balneotherapy is effective in the treatment of patients with inflammatory and noninflammatory joint diseases. Mud pack therapy is applied to the whole body alone, or in combination with other modalities of balneotherapy; it has proved to improve the symptoms of rheumatoid arthritis and osteoarthritis [13] - [16]. The company in Israel [15] near the Dead Sea has developed mud compresses that can be used in patients' homes, without the assistance of a therapist. The compresses are heated in a microwave oven or in a pot of hot water and then applied over painful hands. In contrast to mid packs, mud compresses do not soil the body. The mud compresses are composed of three layers: the first is comprised of a porous fibrous cloth which allows the diffusion of certain liquids but almost completely prevents the migration of nonsoluble solid matter. The second layer consists of an absorbent material on which the Dead Sea mud has been spread. The third layer is a non-permeable plastic sheath. The treatment with mud compresses temporarily relieves pain in patients suffering from osteoarthritis of the knees. Mud baths have been known and used in Estonia and Latvia for many years, but their mechanism is not fully understood. Mud is a mixture of inorganic and organic matter with water, which has undergone geological and biological processes user the influenced by various physiological factors. Mud has been used empirically in musculoskeletal and inflammatory joint disease treatment. Antiseptic and substances interchange capacity are attributed to the inorganic components of mud. Mud can be applied locally or totally. The effects of mud-application include: increase in membrane electrical conductivity, absorption phenomena, hyperaemia, activation of enzymes and hormones. Scientific studies have revealed that bath therapy increases skin temperature, has an impact on cardiovascular systems, water-electrolytes balance, neurotransmission (central nervous system, neural conductivity), immune system, enzymes' activation and metabolism [15]. Mud might contain [13] Na, $\mathrm{K}, \mathrm{Ca}, \mathrm{Mg}, \mathrm{NO}_{3}, \mathrm{Cl}, \mathrm{SO}_{4}$ ions; $\mathrm{CaCO}_{3}, \mathrm{MgCO}_{3}, \mathrm{Fe}_{2} \mathrm{O}_{3}$ etc. components. A warm application of mud [14] increases the surface temperature of the specific area of the body where it is applied. It stimulates body warmth receptors, causing vasodilatation. The effects of vasodilatation are: improved blood flow, reduced blood viscosity, improved delivery of leukocytes and lymphatic circulation increases due to increase in permeability of capillary, which helps in removal of waste product.

\section{Cost Effectiveness Analysis}

Musculoskeletal disorders are well recognized as a major public health problem with substantial human and economic costs [17]. In the UK Labour Force Survey, $30 \%$ of those taking sick leave cited MSDs as the main reason [18]. Among the general Dutch population, the 12-month prevalence of MSDs has been estimated to be around $75 \%$, of which $44 \%$ is due to low-back pain and $45 \%$ to neck and shoulder complaints [19]. These high prevalences lead to substantial costs, such as hospital care, general practice costs, and paramedical costs. These direct costs were estimated to be $7.3 \%$ of the allocated health care costs in the Netherlands, thereby being one of the most expensive health areas [20]. Indirect costs due to sickness, absence and work disability are substantial, since MSDs account for $31 \%$ of the total costs of long-term work disability [21]. However, these direct and indirect costs do not cover the full burden of MSDs, as a health problem may also affect work ability, causing reduced productivity while the worker is still on the job (sickness presenteeism) [22]. Therefore, both absenteeism and presenteeism should be taken into consideration when all costs due to MSDs are calculated. In a study among the Swedish workforce, approximately one-third of all workers reported that they had gone to work twice or more during the preceding year, despite the feeling that they should have taken a sick leave [23]. Reduced productivity was common among the workers returning to full duty after sickness absence due to a musculoskeletal disorder. Productivity loss illustrates the importance of the timing of return to work, especially among workers with residual functional disability after return to work. To get better results also the management of the firm has to be engaged in the return-to-work process to guarantee an early and productive return to work for the employee [21], [24]. Measures to decrease early retirement are underway in many countries to increase the rate of working population and lower costs [24].

Prevention is effective - according to the Kuusk investigation in Estonian enterprises [25], every Euro invested per year into the occupational safety and health prevention efforts gives a return of 1.3 Euros.

Risk assessment in the field of occupational health was first mentioned by prof. Rantanen from the Finnish Institute of Occupational Health [26].

\section{MATERIAL AND METHODS}

There are different methods to map the functional status of workers health:

\section{A. Personal Health Status}

A Basic Pain Questionnaire and a Standardised Nordic Questionnaire were used to get the knowledge of the workers health risks connected with their work. The main accent was put on the developing of the musculoskeletal symptoms. 66 office workers and patients with diagnosed MSDs completed baseline questionnaires (e.g., work time, hours/days worked per week) and the Nordic Musculoskeletal Questionnaire. The severity of upper-extremity pain was measured by using a ten- 
point scale. For data processing, the Stata software and the Student T-test were used.

\section{B. Muscle Functions: Myometric Method}

Stiffening is the forgoing stadium to the decrease of blood circulation in muscles. This stadium is the warning stadium for the development of MSDs. A. Vain [27] from the University of Tartu has worked out and designed a myometer (Myoton) that enables to measure the following parametres:

a) the frequency of self-oscillation of the muscle that indicates the condition of blood circulation in the muscle;

b) the velocity of the muscles' attenuation that characterizes the elasticity of the muscle.

The myometric method gives the possibility to evaluate muscle conditions. The myometer allows the determination of the basic indicators of the skeletal muscle condition (stiffness and elasticity). The parametres may be compared to the standard value of a corresponding individual muscle as well as statistically determined population standards may be used to evaluate the health disturbances potentially caused by work.

\section{Workplace Risk Evaluation and Rehabilitation Measurements}

The range of working conditions influencing the development of MSDs is wide: furniture, indoor climate, noise, carbon dioxide concentration, lighting, noise, etc. It is difficult to imagine that lighting influences the development of MSDs, but if the lighting is poor or wrongly directed to the eyes of the workers, they have to work in a static posture with the computer or with industrial equipment. Working with means of transport (tractors, excavators) different risk factors (noise, cold, vibration) are experienced by the worker simultaneously and the speed of the development of MSDs is increased. The Standardized Nordic Questionnaire was conducted to the patients before and after mineral water, heat and balneological therapies. The pain regions and the strength of pain were identified.

\section{RESULTS}

\section{A. Standardized Nordic Questionnaire Results}

66 office workers (the average age 54 years, the length of service 24.8 years and the average workday length 6.8 hours) were studied.

18 industrial workers (from wood processing and textile industries) with the average age 50.6 years, the mean length of service 21.3 years, the body mass index (BMI) 26.3 and the workday length 7.65 hours were investigated.

The results are presented in Table I (pain regions and pain strength). In the group of industrial workers $(N=18)$ the pain was long-lasting, the length of sick leaves was approximately 30 days.

66 office-workers were subjected to the myometric test. In the patients with the diagnosis of abd poll br decrement (working hand muscle disturbance), the average values of frequency were 1.96 (left hand) and 1.86 (right hand), $p<0.001$; the stiffness of the muscle was $244.48 \mathrm{~N} / \mathrm{m}$ (right hand) and $247.14 \mathrm{~N} / \mathrm{m}$ (left hand). The shoulder muscle stiffness ranged from $191.15 \mathrm{~N} / \mathrm{m}$ (right) to $190.66 \mathrm{~N} / \mathrm{m}$ (left shoulder), $p=0.004$. The muscle disturbance was the same for the both hands muscles (1.38).

\section{TABLE I}

THE COMPaRison OF MUSCULOSKELETAL DisturbanCES OF OFFICE $(N=66)$ AND INDUSTRIAL WORKERS (18)

\begin{tabular}{|l|l|l|l|l|}
\hline Pain region & $\begin{array}{l}\text { \% of } \\
\text { complaining } \\
\text { office } \\
\text { workers } \\
(N=66)\end{array}$ & $\begin{array}{l}\text { Pain } \\
\text { strength }\end{array}$ & $\begin{array}{l}\text { \% of } \\
\text { complaining } \\
\text { industrial } \\
\text { workers } \\
(N=18)\end{array}$ & $\begin{array}{l}\text { Pain } \\
\text { strength }\end{array}$ \\
\hline Neck & 56 & 4.18 & 72 & 4.11 \\
\hline Shoulder, right & 27.3 & 3.8 & 61 & 4.62 \\
\hline Shoulder, left & 25.7 & 2.8 & 33 & 4.62 \\
\hline Elbow, right & 6.0 & 4.71 & - & - \\
\hline Elbow, left & 6.0 & 2.12 & - & - \\
\hline Wrist, right & 19.7 & 4.57 & 61 & 4.57 \\
\hline Wrist, left & 4.5 & 4.01 & 61 & 4.57 \\
\hline Back & 37.8 & 4.28 & 44 & 6.43 \\
\hline
\end{tabular}

\section{B. Myometric Research}

18 industrial workers were also subjected to the myometric test. In the subjects with the diagnosis of abd poll $b r$ decrement (working hand muscle disturbance), the average values were 2.0 (right hand) and 1.6 (left hand), $p<0.001$; so there was a significant difference between the hands. Stiffness significantly deviated from the norm: $311.4 \mathrm{~N} / \mathrm{m}$ (right hand) and $348.8 \mathrm{~N} / \mathrm{m}$ (left hand), $p=0.004$.

Normal parameter values of the myotometre test are: frequency characterising muscle tension: $11 \mathrm{~Hz}-16 \mathrm{~Hz}$; decrement, characterising muscle flexibility: 1.0-1.2; stiffness, characterising muscle's property: $150 \mathrm{~N} / \mathrm{m}-300 \mathrm{~N} / \mathrm{m}$ ) [30].

\section{Rehabilitation and Prevention}

40 SPA workers with professional overuse of upper extremities passed the balneologic treatment ( 9 times) in the outpatient clinic. The average age of the workers was 51.9 years, body mass index (BMI) 27.7 and the length of service 10.6 years. The Nordic Standardised Questionnaire for MSDs was used. The differences in pain intensity (on a 10-point scale) reported before and after mud treatment were visible. The data on pain mean strength and the regions are given in Table IIA and Table IIB.

The $1^{\text {st }}$ group (14 persons) underwent the balneologic treatment (average age: 53.0; the length of service: 12.2 years, BMI: 28.5). The $2^{\text {nd }}$ group (17 persons) underwent the mineral water and local heat mud treatment. The average age of the patients was: 50.5; the length of service: 10.7 years, BMI: 28.5. The $3^{\text {rd }}$ group (9 persons) underwent the local heat treatment with mud. The average age was 54.5 years, BMI: 25.2; the length of service: 9.4 years.

There were 18 persons ( $45 \%$ of all) who had pain in some region of the body estimated at more than 5 points (considered as the value of the moderate pain in muscles) according to 10 -point scale. 
TABLE IIA

The Pain Regions And the Strength of THE Pain Before AND After the MUD TREATMENT OF SPA WORKERS ( $1^{\text {ST }}$ GROUP)

\begin{tabular}{|l|l|l|l|}
\hline Body region & $\begin{array}{l}\text { \% of } \\
\text { complaining } \\
\text { workers (14) }\end{array}$ & $\begin{array}{l}\text { Pain strength } \\
\text { before the } \\
\text { treatment }\end{array}$ & $\begin{array}{l}\text { Pain strength } \\
\text { after the } \\
\text { treatment }\end{array}$ \\
\hline Neck & 58 & 3.8 & 1.9 \\
\hline Shoulders & 35 & 3.5 & 2.0 \\
\hline Elbows & 50 & 1.3 & 0.8 \\
\hline Wrist, right & 58 & 3.5 & 1.9 \\
\hline Back & 45 & 3.7 & 2.5 \\
\hline
\end{tabular}

TABLE IIB

The PAIn Regions And the StRENGTH of THE PAIN Before AND AFter Mineral WATER AND Hot Mud TREATMENT OF SPA WORKERS ( $2^{\text {sT }}$ GrouP)

\begin{tabular}{|l|l|l|l|}
\hline Body region & $\begin{array}{l}\text { \% of } \\
\text { complaining } \\
\text { workers (17) }\end{array}$ & $\begin{array}{l}\text { Pain strength } \\
\text { before the } \\
\text { treatment }\end{array}$ & $\begin{array}{l}\text { Pain strength } \\
\text { after the } \\
\text { treatment }\end{array}$ \\
\hline Neck & 89 & 2.6 & 0.3 \\
\hline Shoulders & 45 & 4.2 & 2.2 \\
\hline Elbows & 13 & 1.5 & 1.3 \\
\hline Wrist, right & 75 & 2.8 & 1.2 \\
\hline Back & 46 & 2.8 & 1.5 \\
\hline
\end{tabular}

\section{DISCUSSION}

$37 \%$ of the computer workers (66 in total) indicated on the pain in the neck, whereas only $21 \%$ of garment workers (previous study, [12]) did so. Conversely, the lower back pain was suffered by $46 \%$ of the garment workers and only by $25 \%$ of the office workers. The data on pain from the current study (18 workers from wood and textile industry), were as follows: pain in the neck: $72 \%$ of workers; pain in the back: $44 \%$ (Table I). So, the results might be contemporary. Further research is needed involving a larger number of patients and considering different industries, where the MSDs occur. The comparison with other authors: in SPA workers, the mean pain was assessed as 3.8; for the investigated wood and textile workers - as 4.11; for the office-workers - 4.18. Comparison to Öztürk \& Esin data [28]: the mean 3.5 (the average age of the investigated female workers was 30.2). The work age of sewers in the study by Wang et al. [29] was 13 years; the mean pain score was 1.4. The study conditions are different, therefore it is difficult to compare the results. The conclusion is that MSDs development in different countries for certain groups of workers (garment, wood processing, service sector) is enormous and the networking in this area would be recommended to get better results for their prevention.

\section{CONCLUSION}

Consequently, the myometrical muscle study could be used as an auxiliary diagnostic method as well as an initial study in the course of physical examination in order to evaluate possible hand muscle overload. Different methods to map the functional status and the environmental situation at the workplace have been discussed. The balneologic treatment is safe and effective therapy for the overuse syndromes and could be used as an early rehabilitation before disability appears. Both methods are useful for preventing the development of occupational diseases and prolonging the work-life of the ageing workforce in Estonia. The research proves the necessity of the support economic analysis to indicate the seriousness of the problem and to attract attention of the officials to undertake concrete actions.

\section{FUTURE RESEARCH}

MSDs have developed in sewing (garment) industrial operators. Long term duration, sustained low level muscle activity work and precise hand work are the main risk factors of neck-shoulder disorders for sewing machine operators. A surface electromyogram (sEMG) offers a valuable tool to determine muscle activity (internal exposure) and quantity muscular load (external exposure). During the sustained and/or repetitive muscle contractions, typical changes of muscle fatigue in sEMG, as an increase in the amplitude or a decrease as a shift in spectrum towards lower frequencies, can be observed [30]. There are some interesting solutions for improvement of workplace ergonomics, like sitting on an exercise ball [31]. The quantitative analysis of post-occlusive reactive hyperaemia (the blood circulation disturbances) is measured with Laser-Doppler perfusion monitoring on extremities (based on three parameters: two time constants and the ratio of the maximum flux and the resting flux). LaserDoppler measurements should be carried out before and after the heat and balneological therapies.

\section{REFERENCES}

[1] European Agency for Safety and Health at Work, "Work-related musculoskeletal disorders: back to work report", 2007.

[2] European Foundation for the Improvement of Living and Working Conditions, "Fourth European working conditions survey," 2005.

[3] "Fit for Work? Musculoskeletal Disorders in the European Workforce," [Online]. Available: http://www.fitforworkeurope.eu/Downloads/WebsiteDocuments/Fit\%20for\%20Work\%20pan-European\%20report.pdf.

[4] K. Zheltoukhova and S. Bevan, "Workability in Estonia? The musculoskeletal disorders and the labour market in Estonia," The Work Foundation Part of Lancaster University, 2011.

[5] "Recognizing and Preventing Occupational Disease: Strategies and Recommendations from Canadians," Canadian Centre for Occupational Health and Safety, October, 2005, p. 74.

[6] National Labour Inspectorate of Estonia, "Annual Report of Work Environment," 2010.

[7] "Documents of the XX World Congress on Safety and Health at Work 2014," [Online]. Available: https://www.safety2014germany.com/en/ programme/programme.html.

[8] M. F. Barbe and A. E. Barr, "Inflammation and the pathophysiology of work-related musculoskeletal disorders," Brain Behavior Immunity, Sep. 2006, vol. 20, no. 5, pp. 423-429. http://dx.doi.org/10.1016/j.bbi.2006.03.001

[9] Zhang F. R., He Li-Hua, Wu Shan-Shan, Li Jing-Yun, Ye Jing-Yun, Ye Kang-Pin and W. Sheng, "Quantity work load and muscle functional activation patterns in neck-shoulder muscles of female sewing machine operators using surface electromyogram," Chinese Medical Journal, 2011, vol. 124, no. 22, pp. 3731-3737.

[10] R. Viir, K. Laiho, J. Kamarenko and M. Mikkelsson, "Repeatability of Trapezius Muscle Tone Assessment by a myometric method," Journal of Mechanics in Medicine and Biology," 2006, vol. 6, no. 2, pp. 215-228. http://dx.doi.org/10.1142/S0219519406001856

[11] W. I. Jezelenberg, D. Molenaar and A. Burdorf, "Different risk factors for musculoskeletal complaints and musculoskeletal sickness absence," Scand. J. Work Environ. Health 2004, vol. 30, no. 1, pp. 56-63. http://dx.doi.org/10.5271/sjweh.765 
[12] K. Reinhold, P. Tint, V. Tuulik and S. Saarik, "Innovations at Workplace: Improvement of Ergonomics," Engineering Economics, 2008, vol. 60, no. 5 , pp. $85-94$.

[13] A. Chadzopulu, J. Adranoitis and E. Theodosopoulou, "The therapeutic effects of mud," Progress in Health Sciences, 2011, vol. 1, no. 2, pp. 132-136.

[14] L. Espejo-Antunez, M. A. Cardero-Duran, E.-M. Garrido-Ardila, S. TorresPiles and B. Caro-Puertolas, "Clinical effectiveness of mud pack therapy in knee osteoarthritis," Rheumatology, Dec. 11, 2012, vol. 52, no. 4. pp. 659-668. http://dx.doi.org/10.1093/rheumatology/kes322

[15] S. Codish, M. Abu-Shakra, D. Flusser, M. Friger and S. Sukenik, "Mud compress therapy for the hands of patients with rheumatoid arthritis," Rheumatology International, Jan. 2005, vol. 25, no. 1, pp. 49-54. http://dx.doi.org/10.1007/s00296-003-0402-4

[16] E. Odabasi, M. Turan, H. Erdem and F. Tekbas, "Does mud pack treatment have any chemical effect? A randomized controlled clinica study," Journal of Alter Complement Med., June 2008, vol. 14, no. 5, pp. 559-565. http://dx.doi.org/10.1089/acm.2008.0003

[17] J. A. Barondes, Musculoskeletal disorders and the workplace: low back and upper extremities, Washington (DC): National Academy Press, 2001, p. 492.

[18] K. T. Palmer, E. C. Harris, C. Linaker, M. Barker, W. Lawrence, C. Cooper and D. Coggon, "Effectiveness of community - and workplace-based interventions to manage musculoskeletal-related sickness absence and job loss - a systematic review," Rheumatology Advance Access, Mar. 16, 2011, pp. 1-13. http://dx.doi.org/10.1093/rheumatology/ker086

[19] H. S. Picavet, and J. S. Schouten, "Musculoskeletal pain in the Netherlands: prevalences, consequences and risk groups, the DMS(3)-study," Pain, Mar. 2003, vol. 102, no. 1-2, pp. 167-168. http://dx.doi.org/10.1016/s0304-3959(02)00372-x

[20] W. J. Meerding, L. Bonneux, J. J. Polder, M. A. Koopmanschap and P. J. van der Maas, "Demographic and epidemiological determinants of healthcare costs in Netherlands: cost of illness study," BMJ, 1998, vol. 317, pp. 111-115. http://dx.doi.org/10.1136/bmj.317.7151.111

[21] M. Hagberg, E. W. Tornqvist and A. Toomingas, "Self-reduced productivity due to musculoskeletal symptoms: associations with workplace and individual factors among white-collar computer users," $J$. Occup. Rehabil., 2002, vol. 12, pp. 151-162. http://dx.doi.org/10.1023/A:1016890527520

[22] F. Lötters, W.-J. Meerding and A. Burdorf, "Reduced productivity after sickness absence due to musculoskeletal disorders and its relation to health outcomes," Scand. J. Work Environ. Health, 2005, vol. 31, no. 5 , pp. 367-374. http://dx.doi.org/10.5271/sjweh.920

[23] G. Aronsson, K. Gustavson and M. Dallner, "Sick but yet at work: an empirical study of sickness presenteeism," J. Epidemiol Community Health, 2000; vol. 54, pp. 502-509. http://dx.doi.org/10.1136/jech.54.7.502

[24] K. Uegaki, M. C. de Bruije, J. R. Anema, A. J. van der Beek, M. W. van Tulde and W. Mechelen, "Consensus-based findings and recommendations for estimating the costs of health-related productivity loss from a company's perspective," Scand. J. Work Environ. Health, 2007, vol. 33, no. 2, pp. 122-130. http://dx.doi.org/10.5271/sjweh.1115

[25] K. Kuusk, "Safety - occupational health and prevention activities of the micro-economic impact on businesses," M. S. Thesis, Tallinn University of Technology, 2013 (in Estonian).

[26] J. Rantanen, "Risk assessment and the setting priorities in occupational health and safety," Scand. J. Work Environ. Health, 1981; 7. Suppl. 4 pp. 84-90.

[27] A. Vain and T. Kums, "Criteria for preventing overtraining of the musculoskeletal system of gymnasts," Biology of Sport, 2012, vol. 19 , pp. 329-345.

[28] N. Öztürk and N. M. Esin, "Investigation of musculoskeletal symptoms and ergonomic risk factors among female sewing machine operators in Turkey," Intenational Journal of Industrial Ergonomics, 2011, vol. 41, no. 6, pp. 585-591. http://dx.doi.org/10.1016/j.ergon.2011.07.001

[29] P. Wang, D. Rampel, R. Harrison, J. Chan and B. Ritz, "Work-organizational and personal factors associated with upper body musculo- skeletal disorders among sewing machine operators," Occup. and Environ. Med., 2009, vol. 64, pp. 806-813. http://dx.doi.org/10.1136/oem.2006.029140

[30] A. Vain, "Biomechanics," University of Tartu, 2011

[31] I. Kingma and J. H. van Dieen, "Static and dynamic postural loadings during computer work in females: Sitting on an office chair versus sitting on an exercise ball," Applied Ergonomics, 2009, vol. 40, no. 2, pp. 199-205. http://dx.doi.org/10.1016/j.apergo.2008.04.004

Viive Pille is a Doctoral student with the Institute of Clinical Medicine and The Department of Work Environment and Safety of Tallinn University of Technology. She is currently an Occupational Health Physician in the Estonian Occupational Medicine Centre. Her main research interests are related to the investigations of work-related musculoskeletal disorders, myometry, fatigue, etc. She has supervised several Master Theses on occupational health. She has published 10 research papers.

The most significant paper is "Computer Users' Health Risks Caused by the Influence of Inadequate Indoor Climate and Monotonous Work" published in the journal "Agronomy Research".

E-mail: viive.pille@ regionaalhaigla.ee

Varje-Riin Tuulik graduated from the Faculty of Medicine of Tartu University. She is currently a Senior Doctor with Tallinn Central Hospital. She is active in the investigations for rehabilitation of patients with MDSs and MDS prevention possibilities. She has published over 10 scientific papers. Her main interest is mud treatment. She has participated as an expert in the European Social Fund project - „Program-based rehabilitation development” and as an expert on work ability in the project of the Estonian Ministry of Social Affairs. She is an active member of the Centre of Excellence in Health Promotion and Rehabilitation of Tallinn University Haapsalu College. Her most significant paper is "Laser-doppler perfusion monitoring" published in the Journal of Rehabilitation Medicine.

E-mail: varje.tuulik@regionaalhaigla.ee

Piia Tint received the Diploma of Chemical Engineer in 1970 from Tallinn Technical University, the degree of Candidate of Technical Sciences in 1977 from Leningrad Technological Institute Lensoveta. His specialty is occupational health and safety.

Since 2000, she has been a Professor of Work Environment and Safety and Head of the Department of Work Environment and Safety of Tallinn University of Technology, Estonia.

She has published 150 scientific papers, 10 books. Her most significant scientific paper is "Hazards Profile in Manufacturing: Determination of Risk Levels towards Enhancing the Workplace Safety" published in the Journal of Environmental Engineering and Landscape Management. Her main research interests are: risk assessment in the work environment, chemical risks. She is a supervisor of $6 \mathrm{PhD}$ students ( 3 defended).

E-mail: piia.tint@ttu.ee

Viiu Tuulik received the degree of Master of Medical Sciences in 1974 and the Doctor of Medicine degree in 1993 from Tartu University. He is currently a Senior Researcher with the Department of Biomedical Engineering, Technomedicum of Tallinn University of Technology. His main research interests are: occupational stress caused by chemicals, physiology, musculoskeletal disorders. He has more than 40 years of experience in occupational health. $\mathrm{He}$ is the author of 100 scientific papers. The most significant paper is "Indoor Air Quality in Educational Institutions in Estonia" published in the Environmental Engineering and Management Journal.

E-mail: viiu@cb.ttu.ee

Aaro Hazak received the $\mathrm{PhD}$ degree in Economics in 2008. He is a Professor in Economic Theory with the Department of Finance and Economics of Tallinn University of Technology. He is the organizer of several international conferences on economics. He is a member of editorial boards of several journals on economics and finance. His most significant paper is "Indicators of corporate default. An EU based empirical study" published in the journal "Transformation in Business \& Economics".

E-mail: aaro.hazak@ttu.ee 